\title{
Eksplorasi Etnomatematika Rumah Gadang Minangkabau Sumatera Barat
}

\author{
Yulia Rahmawati. Z1, Melvi Muchlian² \\ Aktuaria, Pertanian, Universitas Tamansiswa, Padang \\ yulia rahmawatiz@ymail.com
}

Received: 23 September 2019; Accepted: 12 Desember 2019; Published: 29 Desember 2019

\begin{abstract}
Abstrak
Pendidikan dan budaya adalah sesuatu yang tidak dapat dipisahkan dalam kehidupan sehari-hari. Etnomatematika hadir untuk menjembatani antara budaya dan pendidikan khususnya dalam pembelajaran matematika. Tanpa disadari masyarakat telah melakukan berbagai aktivitas dengan meggunakan konsep dasar matematika dan ide-ide matematis. Misalnya, aktivitas berhitung dengan menyebutkan suatu bilangan, aktivitas mengukur (panjang, luas, volume, dan berat), kesenian, permainan, aktivitas jual beli (menghitung uang kembalian, laba atau rugi, dan sebagainya), dan arsitektur bangunan (Rumah Adat). Penelitian ini bertujuan untuk mengkaji dan menganalisis eksplorasi etnomatematika Rumah Gadang Minangkabau Sumatera Barat agar diperoleh informasi dasar dalam pengembangan ilmu etnomatematika terhadap pembelajaran matematika bidang geometri khusus pada bentuk dan ukiran rumah gadang minangkabau. Jenis penelitian ini adalah penelitian eksploratif dengan menggunakan pendekatan etnografi dengan analisis taksonomi. Berdasarkan hasil penelitian yang dilakukan, terdapat unsur dan konsep matematika yang digunakan dalam melakukan aktivitas pembuatan rumah gadang minangkabau. Tanpa mempelajari teori tentang konsep-konsep matematika tersebut, masyarakat Minangkabau telah menerapkan konsep matematika dalam kehidupan sehari-hari. Terbukti adanya bentuk etnomatematika masyarakat minangkabau yang tercermin melalui berbagai hasil aktivitas matematika yang dimiliki dan berkembang di masyarakat minangkabau, meliputi: 1) aktivitas membuat rancangan pembangunan rumah gadang; dan 2) aktivitas membuat pola ukiran pada motif ukiran dinding rumah gadang.
\end{abstract}

Kata kunci: Etnomatematika, Rumah Gadang, Geometri, Eksploratif, Etnografi.

\begin{abstract}
Education and culture are things that cannot be separated from everyday life. Ethnomatematics is present to bridge between culture and education, especially mathematics learning. Without realizing it, the community has carried out various activities by using basic concepts of mathematics and mathematical ideas. For example, counting activities by mentioning a number, measuring activities (length, area, volume, and weight), art, games, buying and selling activities (calculating change, profit or loss, etc.), and building architecture. This study aims to study and analyze the exploration of ethnomatematic Rumah Gadang Minangkabau in West Sumatera in order to obtain basic information in the development of ethnomatematics on learning mathematics in geometry specifically on the shape and carving of the Rumah Gadang Minangkabau. This type of research is exploratory research using an ethnographic approach with taxonomic analysis. Based on the results of the research carried out, there are elements and mathematical concepts used in carrying out the activities of making a Rumah Gadang Minangkabau. Without learning the theory of these mathematical concepts, Minangkabau people have applied mathematical concepts in everyday life. Evidently the form of ethnomatematics of the Minangkabau community is reflected through the various results of mathematical activities that are owned and developed in the Minangkabau community, including: 1) the activity of designing the building of a Rumah Gadang; and 2) the activity of making carving patterns on the motifs of carving the walls of the Rumah Gadang.
\end{abstract}

Keywords: Ethnomatematics, Rumah Gadang, Geometry, Exploration, Ethnography. 



\section{PENDAHULUAN}

Pendidikan dan budaya adalah sesuatu yang tidak dapat dipisahkan dalam kehidupan sehari-hari. Pendidikan merupakan kebutuhan dasar bagi setiap individu dalam masyarakat sedangkan budaya merupakan kesatuan yang utuh dan menyeluruh yang berlaku dalam suatu masyarakat, nilai dan idenya dihayati oleh sekelompok manusia di suatu lingkungan hidup tertentu dan disuatu kurun waktu tertentu (Ratna, 2005). Sedangkan menurut ilmu antropologi, budaya merupakan keseluruhan sistem gagasan, tindakan, dan hasil karya manusia dalam kehidupan masyarakat yang dijadikan milik diri manusia dengan belajar (Koetjaraningrat, 1985). Hal ini berarti bahwa hampir seluruh aktivitas dan kegiatan manusia merupakan budaya atau kebudayaan karena hanya sedikit sekali tindakan manusia dalam rangka kehidupan masyarakat yang tidak memerlukan belajar dalam membiasakannya. Sedangkan ahli sejarah budaya mengartikan budaya sebagai warisan atau tradisi suatu masyarakat. Ilmu matematika sudah menjadi bagian dari kebudayaan manusia. Namun, sebagian besar masyarakat sering tidak menyadari bahwa mereka telah menerapkan ilmu matematika dalam kehidupan sehari-hari. Mereka memandang bahwa matematika hanyalah suatu mata pelajaran yang dipelajari di bangku sekolah.

Berdasarkan hasil studi dari TIMSS (Trends in International Mathematics and Science Study) pada tahun 2011, Indonesia berada pada urutan yang sangat rendah di bawah rata-rata dan jauh tertinggal dari negara tetangga seperti Singapura, Malaysia dan Thailand. Hal ini disebabkan kurangnya pemahaman siswa dalam penalaran dan pemecahan masalah sehingga siswa kurang mampu menyelesaikan soal-soal yang berkaitan dalam penalaran dan pemecahan masalah khususnya pada permasalahan geometri. Selain itu, berdasarkan fakta di masyarakat, belajar hanya sebagai tolak ukur untuk mencapai nilai saja bukan berdasarkan bagaimana siswa itu memahami dan menyelesaikan permasalahan yang diberikan. Padahal, dalam kehidupan bermasyarakat siswa tidak menyadari bahwa selama ini mereka sudah menerapkan ilmu matematika di dalam kehidupannya.

Beberapa tahun belakangan ini mulai banyak dikaji penelitian yang menghubungkan antara matematika dan budaya. Menurut Sroyer, et al (2018), dari hasil pertemuan International Community of Mathematics Education menyebutkan bahwa permasalahan yang terkait dengan budaya mau tidak mau akan mengelilingi proses pembelajaran matematika, bahkan semua bentuk matematika. Karakteristik matematika yang abstrak, menyebabkan banyak siswa masih berada dalam keadaan cemas jika mempelajari matematika dan kebanyakan siswa mengalami kesulitan dalam mengaplikasikan matematika ke dalam situasi kehidupan real. Ini menunjukkan bahwa belajar matematika siswa belum bermakna, sehingga pengertian siswa tentang konsep sangat lemah. Guru perlu mengaitkan skema yang telah dimiliki oleh siswa dan memberi kesempatan untuk menemukan kembali dan mengkonstruksi sendiri ide-ide matematika. Oleh sebab itu, pembelajaran matematika sangat memerlukan pendekatan etnomatematika untuk mengajarkan konsep matematika yang abstrak kepada siswa. Salah satu cara untuk mengemas agar pembelajaran matematika lebih bermakna yaitu dengan mengaitkan pada konteks kehidupan disekitar siswa atau budaya yang sudah mengakar sehingga ini menjadi sesuatu yang konkret dan bermakna dibenak siswa. Hal ini membuat siswa tidak mudah lupa tentang 
materi matematika yang telah dipelajarinya dikarenakan masalah tersebut sering dijumpainya dalam kehidupan sehari-hari. Selain itu, siswa akan terbiasa untuk mengaitkan setiap materi matematika dengan budaya yang ada pada kehidupan sehari-hari.

Selain itu, menurut Fajriyah (2018) peran etnomatematika juga mendukung literasi matematika dengan memfasilitasi siswa untuk mampu mengkonstruksi konsep matematika sebagai bagian dari literasi matematika berdasarkan pengetahuan siswa tentang lingkungan sosial budaya mereka.

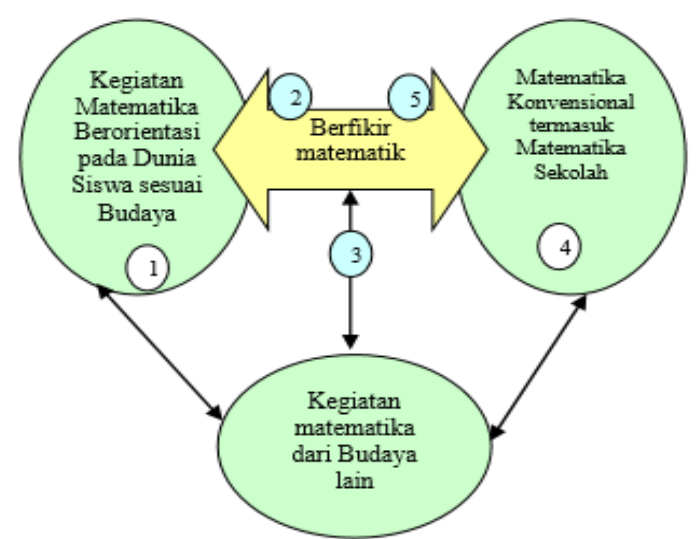

\section{Gambar 1. Kerangka Satuan Kurikulum Etnomatematika}

Model kerangka satuan kurikulum ini membentuk hubungan antara bidang kegiatan matematika. Hubungan tersebut ditunjukan dengan anak panah besar menghubungkan kegiatan matematika menurut budaya siswa menuju matematika konvensional atau matematika sekolah yang diistimewakan oleh satuan kurikulum etnomatematika.

Wahyuni, et al (2013) menyatakan bahwa salah satu yang dapat menjembatani pedidikan dan budaya khususnya pendidikan matematika adalah etnomatematika. Tanpa disadari masyarakat telah melakukan berbagai aktivitas dengan meggunakan konsep dasar matematika dan ide matematis. Misalnya, aktivitas berhitung dengan menyebutkan suatu bilangan, aktivitas mengukur (panjang, luas, volume, dan berat), kesenian, permainan, aktivitas jual beli (menghitung uang kembalian, laba atau rugi, dan sebagainya), dan arsitektur bangunan (Rumah Adat). Konsep dasar tersebut telah mereka pelajari di bangku sekolah dasar. Ide matematis mulai dipandang oleh para ahli pendidikan matematika sebagai suatu hal yang penting. Sifat matematika cenderung linier dan kaku tetapi apabila diintegrasikan dengan sesuatu yang soft seperti budaya, maka pemikiran itu menjadi lentur.

Indonesia merupakan salah satu negara yang memiliki berbagai macam kebudayaan, suku, ras, dan rumah adat. Salah satunya adalah Sumatera Barat yang memiliki rumah adat yang disebut rumah adat Minangkabau atau yang biasa disebut dengan Rumah Gadang. Rumah Gadang adalah salah satu kekayaan budaya Indonesia yang perlu dilestarikan. Kini jumlah rumah gadang yang terdapat di Sumatera Barat semakin lama semakin sedikit.

Rumah gadang banyak tersebar di daerah Sumatera Barat terutama yang terkenal di daerah Batusangkar yaitu Rumah Gadang Istano Basa Pagaruyung dan di daerah Solok Selatan yang disebut negeri 1000 rumah gadang. Rumah Gadang Istano Basa Pagaruyung merupakan replika Istana Minagkabau. Bangunan Rumah Gadang berbentuk sebuah rumah panggung berukuran besar dengan atap gonjong yang menjadi ciri khas dari arsitektur tradisional Minangkabau. Rumah panggung besar ini bertingkat tiga, dengan 72 tonggak yang menjadi penyangga utamanya. Terdapat 11 gonjong atau pucuk atap yang menghias bagian atas dari bangunan ini. Seluruh dinding bangunan ini dihiasi oleh 
ornamen ukiran berwarna-warni yang secara total terdiri dari 58 jenis motif yang berbeda. Bentuk atau motif ukiran ini ada yang berbentuk melingkar atau persegi.

Rumah Gadang didasarkan kepada perhitungan jumlah ruang dalam bilangan yang ganjil dimulai dari tiga. Jumlah ruangan biasanya ada tujuh tetapi ada juga yang jumlah ruangannya tujuh belas. Secara melebar, sebuah Rumah Gadang dibagi dalam didieh, biasanya mempunya tiga didieh. Sebuah didieh digunakan sebagai biliek (ruang tidur), sebuah ruangan yang dibatasi oleh empat dinding yang bersifat khusus dan pribadi (Abdullah, et al 2015).

Andika (2014) menyatakan ukiran ini banyak digunakan sebagai hiasan Rumah Gadang, biasanya ukiran Rumah Gadang ini berbentuk garis melingkar atau persegi, dengan motif seperti tumbuhan merambat, akar yang berdaun, berbunga, dan berbuah. Pola akar ini biasanya berbentuk lingkaran, akar berjajaran, berhimpitan, berjalinan, dan juga sambung menyambung. Motif lainnya yang dijumpai pada rumah gadang adalah geometri bersegi tiga, empat, dan genjang. Pada pembelajaran matematika, ukiran ini erat kaitannya dengan materi geometri bidang dan geometri fraktal. Seperti penelitian yang telah dilakukan Puspadewi \& Putra (2014) mengenai etnomatematika pada kerajinan anyaman Bali yaitu adanya penggunaan prinsip teselasi/pengubinan pada pola anyaman. Teselasi tersebut menggunakan satu jenis bangun geometri yaitu persegi panjang dan persegi.

D’Ambrosio (1985) memperkenalkan suatu istilah yaitu etnomatematika. Ia mengatakan bahwa matematika yang dibelajarkan di sekolah disebut dengan academic mathematics, sedangkan etnomatematika merupakan matematika yang diterapkan dalam kelompok budaya yang terdefinisi seperti masyarakat suku, kelompok buruh, anak-anak dari kelompok usia tertentu, kelas profesional, dan sebagainya. Sehingga dapat dikatakan bahwa etnomatematika merupakan matematika yang muncul dalam suatu kebudayaan tertentu yang dianggap sebagai lensa untuk memandang dan memahami matematika sebagai produk budaya. Budaya yang dimaksud mengacu pada masyarakat, tempat, tradisi, cara mengorganisir, menafsirkan, konseptualisasi, dan memberikan makna terhadap dunia fisik dan sosial.

Proses pembelajaran matematika yang dibutuhkan saat ini adalah pembelajaran yang kontekstual dan realistik dengan menggunakan metode yang bervariasi. Hasil penelitian Pangestu dan Santi (2016) menunjukkan bahwa terdapat korelasi yang cukup tinggi antara pengaruh pembelajaran matematika yang realistik terhadap kesenangan belajar siswa. Dengan demikian, upaya ini dapat mempengaruhi minat siswa untuk mempelajari matematika yang dapat ditemukannya dalam kehidupan sehari-hari. Jika kita lihat di negara lain, berhasilnya negara Jepang dan Tionghoa dalam pembelajaran matematika disebabkan karena mereka menggunakan Etnomatematika dalam pembelajaran matematika. Menurut Gerdes dalam Wahyuni (2016), etnomatematika adalah matematika yang diterapkan oleh kelompok budaya tertentu, kelompok buruh/petani, anak-anak dari masyarakat kelas tertentu, kelas profesional, dan lain sebagainya. Berdasarkan definisi ini, disimpulkan bahwa etnomatematika memiliki pengertian yang lebih luas dari hanya sekedar etno (etnis) atau suku. Oleh sebab itu, pakar etnomatematika berpendapat bahwa pada dasarnya perkembangan matematika sampai kapanpun 
tidak terlepas dari budaya dan nilai yang telah ada pada masyarakat maka penelitian etnomatematika perlu mendapat ruang. Berdasarkan uraian di atas, maka tujuan penelitian ini adalah untuk mengkaji dan menganalisis eksplorasi etnomatematika Rumah Gadang Minangkabau Sumatera Barat agar diperoleh informasi dasar dalam pengembangan ilmu etnomatematika terhadap pembelajaran matematika khususnya bidang geometri. Dengan demikian, peneliti memberikan judul penelitian ini dengan "Eksplorasi Etnomatematika Rumah Gadang Minangkabau Sumatera Barat”. Khususnya tentang bentuk rumah gadang dan seni ukir (motif ukir) rumah gadang.

\section{METODE}

Jenis penelitian ini adalah penelitian eksploratif. Arikunto (2006) menjelaskam "penelitian eskploratif merupakan penelitian yang bertujuan untuk menggali secara luas tentang sebab-sebab atau hal-hal yang mempengaruhi terjadinya sesuatu”. Sedangkan pendekatan yang digunakan dalam penelitian ini adalah pendekatan etnografi yaitu pendekatan yang bertujuan menyelidiki dan mendapatkan deskripsi serta analisis mendalam tentang suatu kelompok kebudayaan berdasarkan penelitian lapangan (fieldwork) dalam periode waktu tertentu secara intensif. Pendekatan ini memusatkan usaha untuk menemukan bagaimana masyarakat mengorganisasikan budaya tersebut dalam pikiran mereka dan kemudian menggunakannya dalam kehidupan sehingga ada dalam pikiran manusia. Metode penelitian yang dilakukan adalah wawancara.

Penelitian dilaksanakan di Museum Adityawarman Padang, Sumatera Barat, Rumah Gadang Istano Basa Pagaruyung Kecamatan Tanjung Emas, Kota Batusangkar, Kabupaten
Tanah Datar Sumatera Barat, dan Seribu Rumah Gadang, Solok Selatan (informan). Peneliti meneliti tentang bagaimana bentuk rumah gadang dan seni ukir (motif ukir) rumah gadang. Instrumen penelitian berupa kuisoner melalui wawancara yang diberikan kepada pemuka adat yakni niniak mamak, cadiak pandai, alim ulama, bundo kanduang, praktisi seni ukir yang memahami tentang seluk beluk bentuk rumah gadang dan motif ukiran rumah gadang. Penelitian ini diawali dengan melakukan survei pada tempat dilakukannya penelitian, penyusunan instrumen penelitian, menentukan jadwal penelitian, dan proses pelaksanaan penelitian dengan memberikan instrumen. Pengumpulan data dilakukan dengan metode wawancara (kuisoner), observasi dan dokumentasi tentang bagaimana bentuk rumah gadang dan motif ukiran rumah gadang. Pada dasarnya data yang akan dianalisis dalam penelitian ini berdasarkan hasil observasi, wawancara, dan dokumentasi yang mengaitkan bagaimana budaya yang terdapat di minangkabau mengandung unsur matematika. Analisis data yang akan dilakukan adalah analisis taksonomi. Analisis taksonomi memusatkan perhatian dan menjabarkan secara rinci pada domain tertentu yang berguna untuk menggambarkan fenomena atau masalah yang menjadi sasaran penelitian. Analisis taksonomi dilakukan untuk membuat kategori dari simbol-simbol budaya yang ada pada kebudayaan yang diteliti.

\section{HASIL DAN PEMBAHASAN Bentuk Rumah Gadang Minangkabau}

Bagi masyarakat Minang, rumah adat Minangkabau (rumah gadang) merupakan simbol tradisi sekaligus tempat untuk melaksanakan berbagai aktivitas dan kegiatan keluarga besar pemilik rumah atau lazimnya 
disebut satu perut (paruik). Mulai dari proses perencanaan, pencarian bahan, tata cara membangun, pilihan model hingga ornamen dekorasi rumah gadang mengandung makna dan falsafah. Konsep matematika sebagai hasil aktivitas merancang bangunan, mengukur, memuat pola, serta berhitung dapat diungkap dari pembuatan rumah adat.

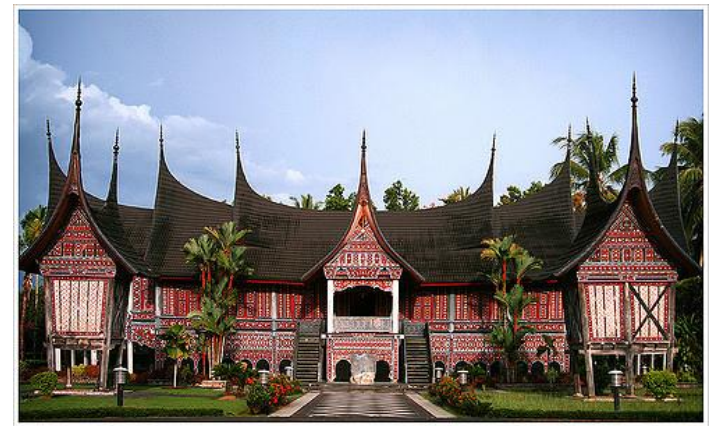

Gambar 2. Rumah Adat Minangkabau

Bentuk dasarnya, rumah gadang berbentuk persegi empat yang tidak simetris dan mengembang ke atas. Atapnya melengkung tajam seperti bentuk tanduk kerbau, sedangkan lengkung badan rumah Iandai seperti badan kapal. Bentuk badan rumah gadang yang segi empat yang membesar ke atas (trapesium terbalik) sisinya melengkung ke dalam atau rendah di bagian tengah. Jika dilihat dari sebelah sisi bangunan (penampang), segi empat yang membesar ke atas ditutup oleh bentuk segi tiga yang sisi segi tiga itu melengkung ke arah dalam, semuanya membentuk suatu keseimbangan estetika yang sesuai dengan ajaran hidup mereka.

Jika dilihat dari segi fungsinya, garis-garis rumah gadang menunjukkan penyesuaian dengan alam tropis. Atapnya yang lancip berguna untuk membebaskan endapan air pada ijuk yang berlapis-lapis itu, sehingga air hujan yang betapa pun sifat curahannya akan meluncur cepat pada atapnya. Bangunan rumah yang membesar ke atas disebut silek, membebaskannya dari terpaan tampias. Kolongnya yang tinggi memberikan hawa yang segar, terutama pada musim panas. Di samping itu, rumah gadang dibangun berjajaran menurut arah mata angin dari utara ke selatan guna membebaskannya dari panas matahari serta terpaan angin. Jika dilihat secara keseluruhan, arsitektur rumah gadang itu dibangun menurut syarat-syarat estetika dan fungsi yang sesuai dengan kodrat atau yang mengandung nilai-nilai kesatuan, kelarasan, keseimbangan, dan kesetangkupan dalam keutuhannya yang padu.

Sebenarnya terdapat beberapa tipe rumah gadang, tetapi yang paling dikenal adalah rumah gadang bagonjong. Rumah adat ini memiliki ciri khas berupa bentuk atap yang menyerupai tanduk kerbau. Konsep matematika dalam pembangunan, mekipun dahulu masyarakat Minangkabau belum mengenal materi dasar konstruksi bangunan seperti halnya yang sekarang diajarkan pada pendidikan formal (seperti konsep siku-siku, simetris, persegi panjang, maupun konsep geometri lainnya), tetapi mereka dapat membangun bangunan yang megah dan tahan lama jika dibandingkan dengan bangunan zaman sekarang.

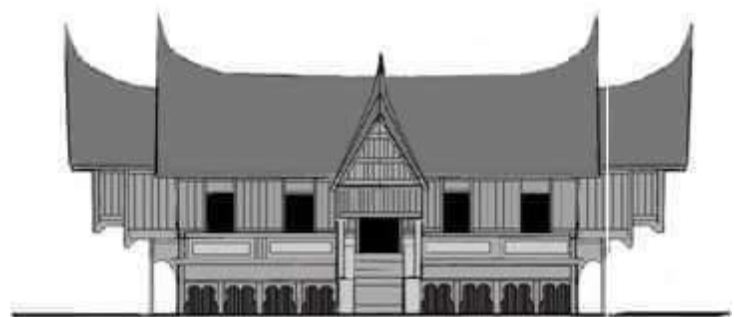

Gambar 3. Rumah Gadang Bergonjong Lima

Makna jumlah atap gonjong rumah gadang Minangkabau mempunyai ciri khas atap 
berbentuk runcing yang disebut gonjong. Jumlah gonjong pada rumah gadang ternyata tidak selalu sama (berbeda). Rumah gadang di Solok Selatan mempunyai jumlah gonjong yang berbeda, dua gonjong hingga paling banyak 14 gonjong. Menurut pemerhati budaya minang, Ir. Hasmurdi Hasan (dalam video youtube), jumlah gonjong memiliki makna tertentu. Rumah gadang bergonjong dua berarti rumah warga biasa, rumah bergonjong empat berarti pemilik rumah seorang datuak, rumah bergonjong enam berarti punya koordinator datuak atau pemimpin adat tertinggi, jika gonjong lebih dari enam buah bukan berarti strata lebih tinggi justru balik lagi dari bawah. Hiasan puncak gonjong pada mulanya memang seperti bentuk tanduk kerbau yang dibuat dari plat seng berbentuk kerucut. Kemudian terdapat berbagai bentuk hiasan yang memiki makna untuk setiap bentuknya. Setelah masuknya Islam terdapat buan dan bintang seagai iasan gonjong (Fitriza, et al, 2018).

Berdasarkan penelitian Fauziah \& Yusfitri (2018), kenagarian di Kabupaten Solok Selatan memiliki berbagai jenis rumah gadang yaitu, 62,96\% jenis surambi aceh begonjong ciek, 25,93\% jenis manifold gajah maharam, 7,41\% gonjong ampek sibak baju. Sedangkan untuk dua kenagarian yang ada di Kabupaten Solok Selatan yaitu Nagari Sapapui dan Nagari Abai Kabupaten Sangir Batang Hari hampir seluruh bentuk atap rumah gadang dalam bentuk simetris dan untuk kanagarian lainnya beragam. Kemudian, terdapat satu kecamatan di Solok Selatan tepatnya di Kenagarian Abai, kecamatan Batang Hari, bahwa rumah gadang mereka tidak memiliki ukiran karena dinding rumah gadang telah diganti menjadi dinding beton. Terdapat 44,44\% rumah gadang di Solok Selatan tanpa ukiran dan 76,47\% dari ukiran motif di rumah gadang Solok Selatan simetris (Fauziah \& Niniwati, 2017).
Dilihat dari bentuk rumah gadang, masyarakat Minangkabau telah mengimplementasikan salah satu ilmu matematika, yaitu Geometri dalam pembangunan bagian-bagian bangunan rumah adat diantaranya model bangun datar, meliputi: persegi, persegi panjang, trapesium, segitiga, segitiga samakaki, segitiga samasisi, segilima, lingkaran serta belah ketupat, model bangun ruang, meliputi: kubus, balok, dan tabung, model sifat matematis, meliputi: sifat simetris, fraktal, dan konsep tranlasi (pergeseran).

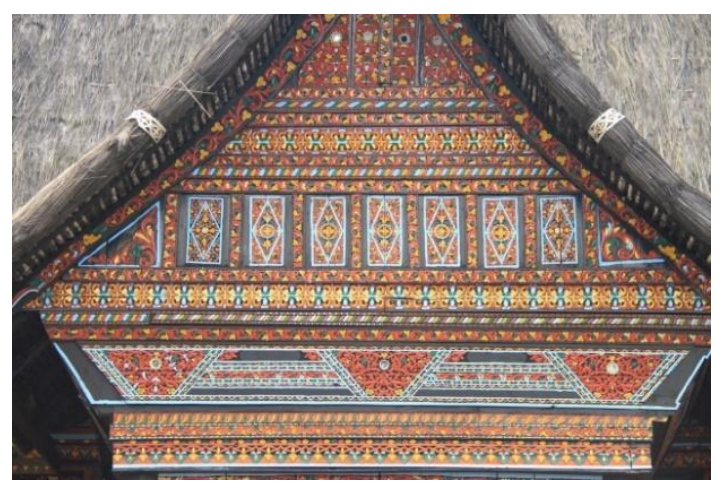

Gambar 4. Model Bangun Datar pada Ornamen Ukiran

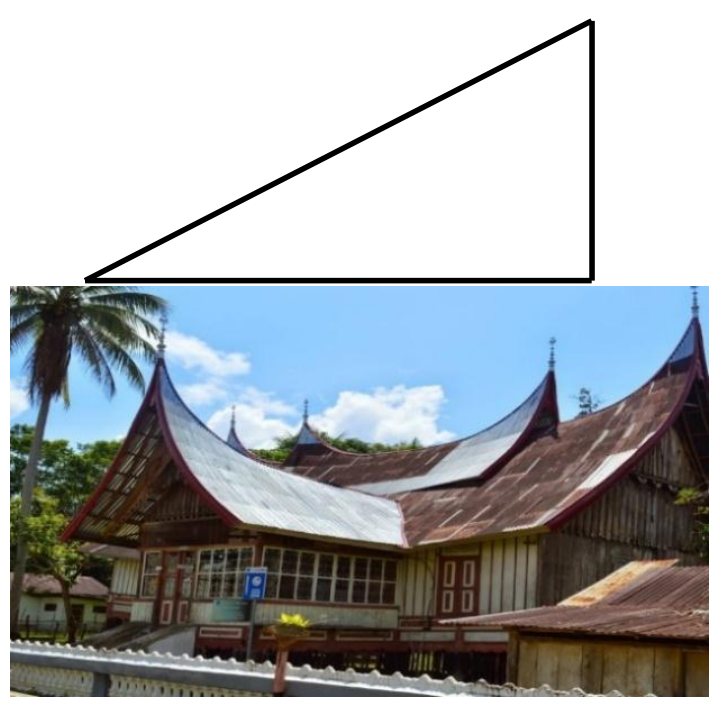

Gambar 5. Rumah Masyarakat Minangkabau 
Pada gambar 5 di atas, terlihat bahwa terdapat konsep/aturan matematika pada jenjang/ tangga rumah gadang, yaitu konsep/aturan Trigonometri dalam menentukan berapa ukuran panjang jenjang/tangga.

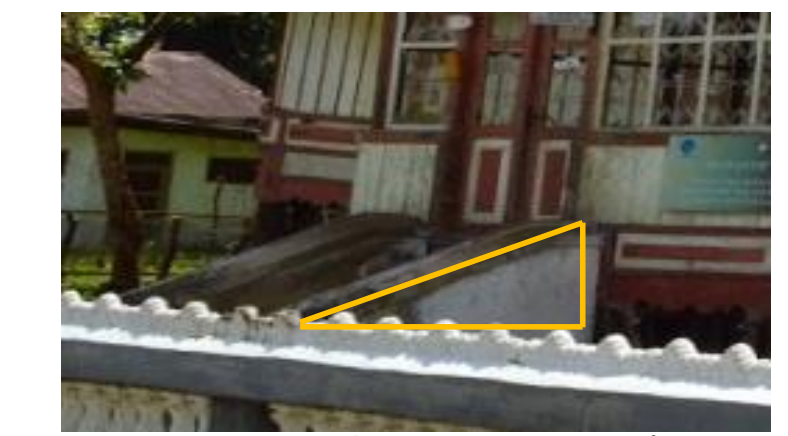

Gambar 6. Konsep/aturan Matematika pada Jenjang/ tangga Rumah Gadang

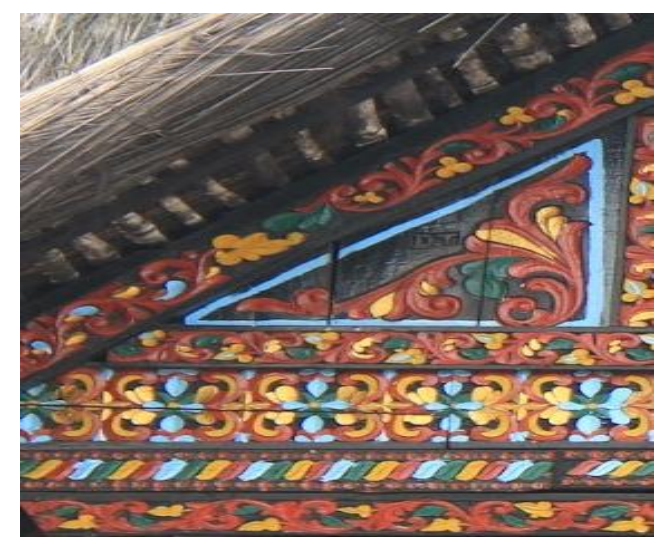

Gambar 7. Konsep/aturan Matematika pada Pembuatan Ukiran Rumah Gadang

\section{Gambar 8. Bentuk Segitiga Siku-siku}

Dalam segitiga siku-siku tersebut dapat ditentukan enam buah perbandingan. Keenam perbandingan itu disebut perbandingan trigonometri pada segitiga siku-siku.

$\sin \alpha^{\circ}=\frac{\text { sisi di depan sudut } \alpha^{\circ}}{\text { sisi miring }}$
$\cos \alpha^{\circ}=\frac{\text { sisi di samping sudut } \alpha^{\circ}}{\text { sisi miring }}$ $\tan \alpha^{\circ}=\frac{\text { sisi di depan sudut } \alpha^{\circ}}{\text { sisi di samping sudut } \alpha^{\circ}}$

$\cot \alpha^{\circ}=\frac{\text { sisi di samping sudut } \alpha^{\circ}}{\text { sisi di depan sudut } \alpha^{\circ}}$

$\sec \alpha^{\circ}=\frac{\text { sisi miring }}{\text { sisi di samping sudut } \alpha^{\circ}}$

$\operatorname{cosec} \alpha^{\circ}=\frac{\text { sisi miring }}{\text { sisi di depan sudut } \alpha^{\circ}}$

Dengan menggunakan konsep trigonometri tersebut kita dapat menentukan berapa kemiringan sudut yang terbentuk pada tangga/jenjang baik dari dasar (sudut elevasi) maupun dari dasar pintu (sudut delevasi).

\section{Ukiran Rumah Gadang Minangkabau}

Dinding rumah gadang terbuat dari kayu dan bagian belakangnya terbuat dari bambu. Kayu yang digunakan untuk membentuk dinding tersebut merupakan kayu pilihan. Kayu tersebut di bentuk menjadi papan. Dinding yang terbuat dari papan tersebut di pasang secara vertikal. Pada setiap sambungan antara papan yang satu dengan yang lain diberi bingkai. Pada jendela dan pintu juga terdapat bingkai yang terbuat dari papan. Bingkai tersebut di pasang dengan lurus. Semua papan dan bingkai ini dipenuhi oleh ukiran. Tidak hanya pada dinding, jendela atau pintu saja, tiang rumah gadang juga sering di ukir dengan berbagai macam gaya ukiran. Sehingga dapat dikatakan, ukiran tersebut merupakan hiasan yang dominan dalam bangunan rumah gadang minangkabau.

Ukiran yang di bentuk tersebut merupakan ragam hiasan bidang. Setiap ukiran pada bagian-bagian di rumah gadang mempunyai ciri khas dan makna tersendiri. Ukiran tersebut juga merupakan sebuah karya seni di minangkabau. Ukiran tersebut bersumber dari motif alam, yang berkaitan dengan falsafah alam yang 
dianut oleh orang minangkabau. Bukan berarti ukiran tersebut dijadikan sebagai bentuk kepercayaan atau sakral maupun sebagai bentuk pemujaan, tetapi ukiran tersebut semata-mata di tampilkan sebagai karya seni yang bernilai hiasan.

“Alam Takambang Jadi Guru” sebagai falsafah orang minangkabau sangat mempengaruhi bentuk dan gaya tampilan ukiran rumah gadang. Biasanya motif ukiran bersumber dari akar tumbuhan merambat. Akar tumbuhan merambat itu di sebut akar yang berdaun, berbunga, dan berbuah. Variasi susunan akar merupakan pola inti ukiran tersebut. ada pola akar berlingkaran, berjajaran, berhimpitan, berjalin, dan bersambung atau sambung-menyambung.

Penamaan ukiran tersebut disesuaikan dengan bentuk polanya. Nama-nama tersebut seperti "kaluak paku, pucuak rambuang, saluak laka, jalo, jarek, itiak pulang patang, dan saik galamai”. Setiap nama dari ukiran tersebut memiliki makna ajaran minangkabau. Penamaan dan pemakaian ukiran tersebut yaitu, "kaluak paku' diartikan sebagai ajaran anak dipangku kemenakan dibimbing. "pucuak rabuang" diartikan sebagai ajaran yang praktis yaitu "ketek baguno, gadang tapakai". "saluak laka" diartikan sebagai lambang kekerabatan di minangkabau yang saling berkaitan. "jalo" melambangkan sistem pemerintahan yang di tuangkan datuak parpatih nan sabatang atau aliran bodi caniago. "jarek" melambangkan sistem pemerintahan yang di ciptakan oleh datuak katumanggungan atau aliran koto piliang. "itiak pulang patang" diartikan sebagai sebuah ketertiban anak-kemenakan. "saik galamai" melambangkan ketelitian. Bentuk ukiran lain yaitu "si kambang manih" yang menggambarkan keramahan.
Tabel 1. Ragam Ukiran Minangkabau

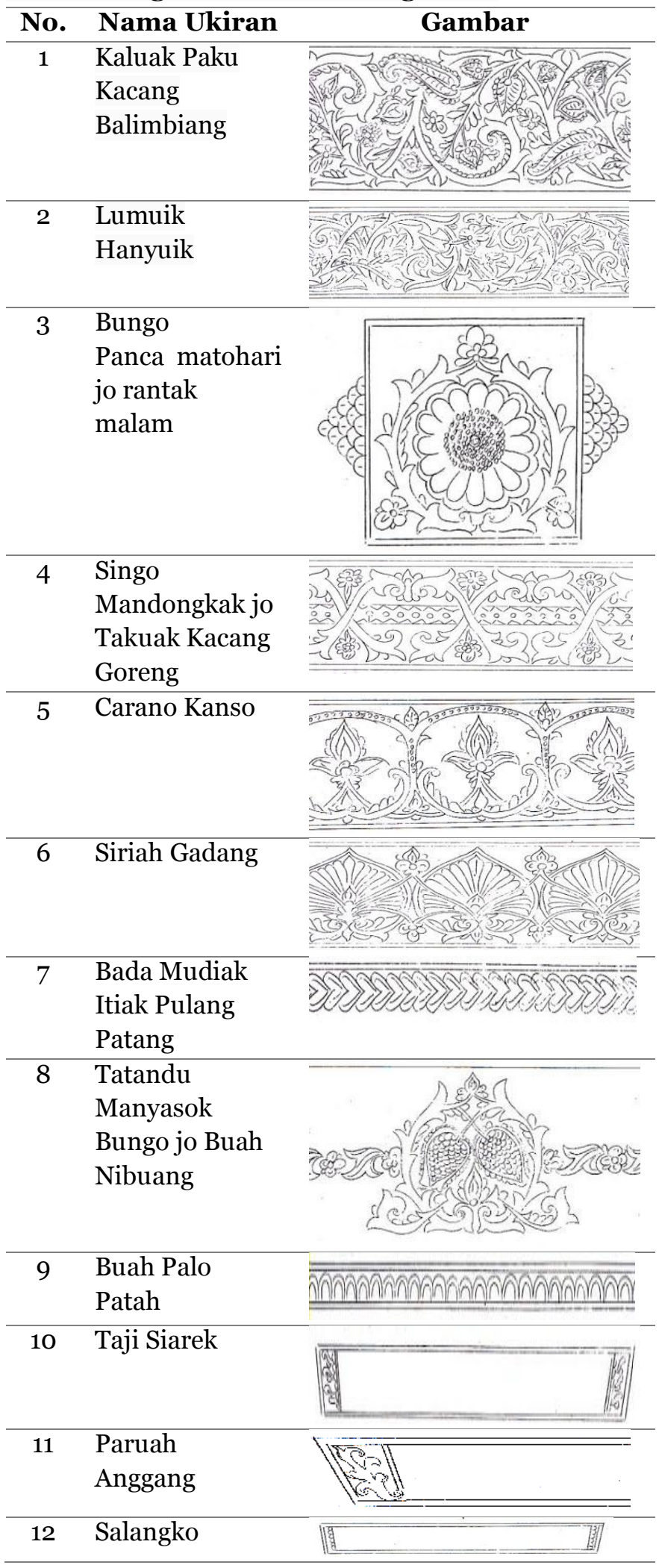




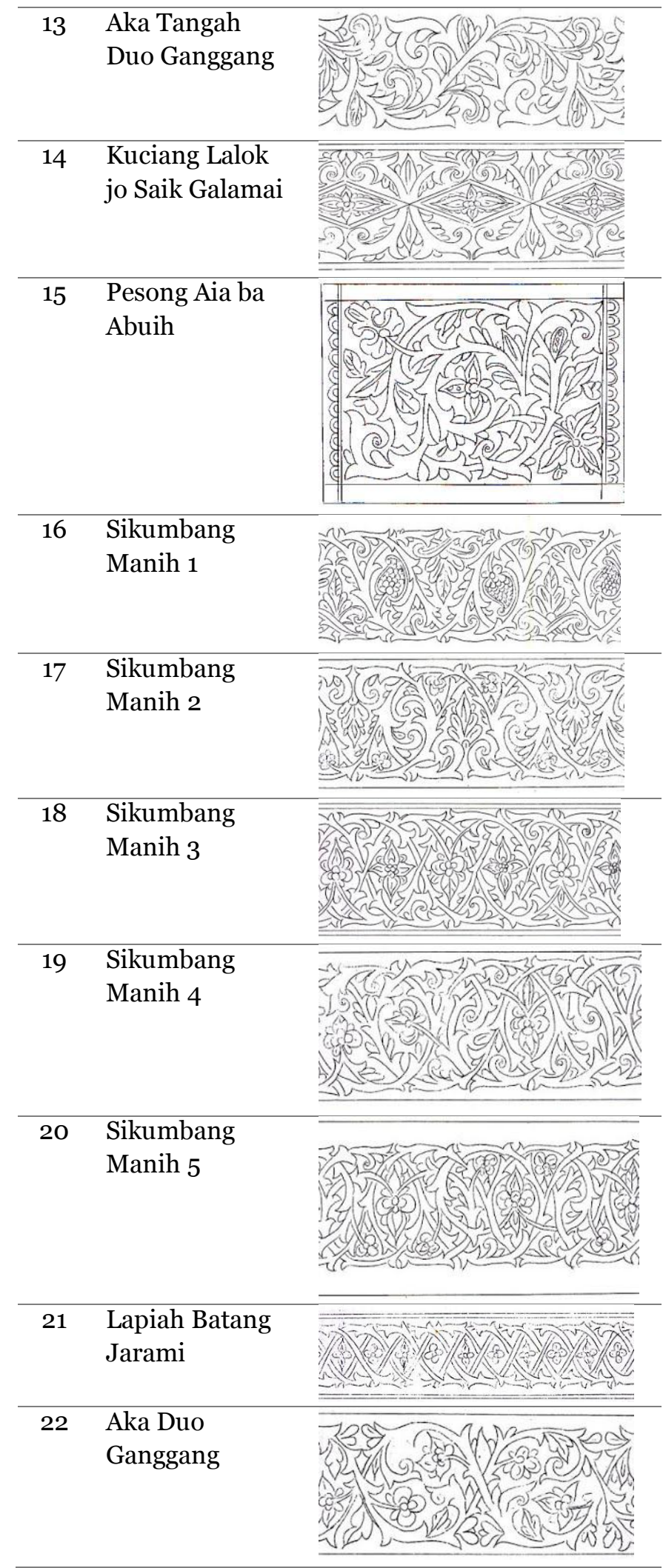

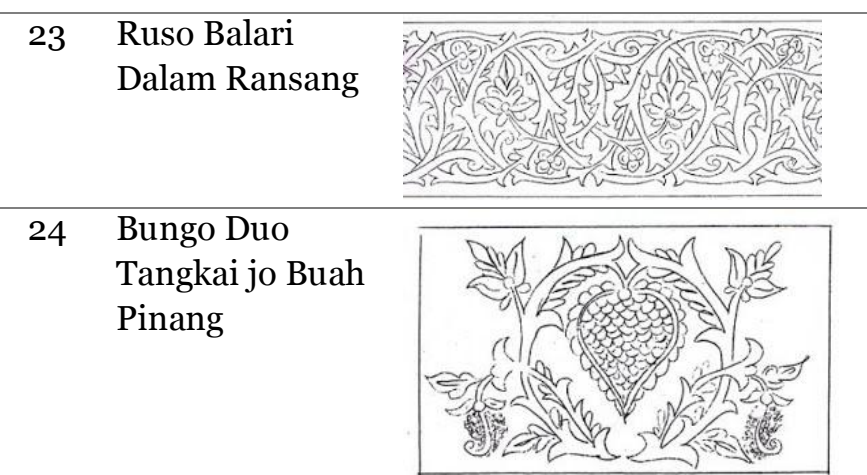

Konsep matematika sebagai hasil aktivitas dalam membuat pola yang dapat diungkapkan dari motif ukiran dinding rumah gadang diantaranya konsep lingkaran, garis lurus dan garis lengkung, simetris, refleksi, dilatasi, translasi, serta rotasi.

\section{Tabel 2. Ragam Ukir Khas Minangkabau pada Dinding Bagian Luar dari Rumah Gadang}

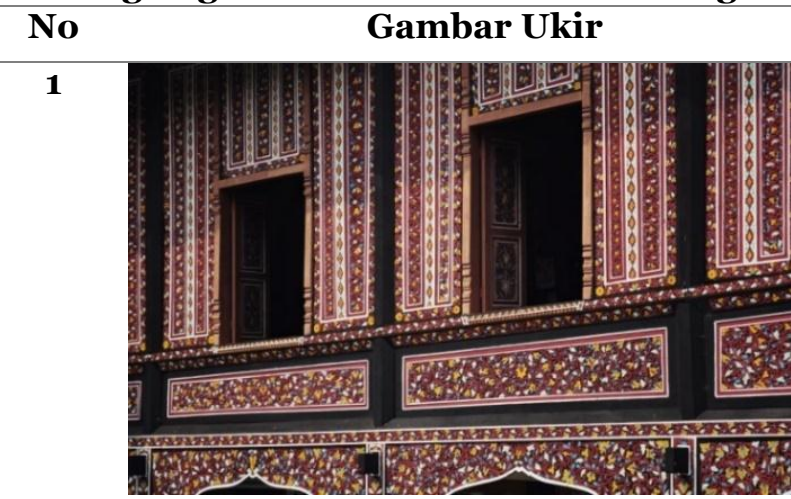

2

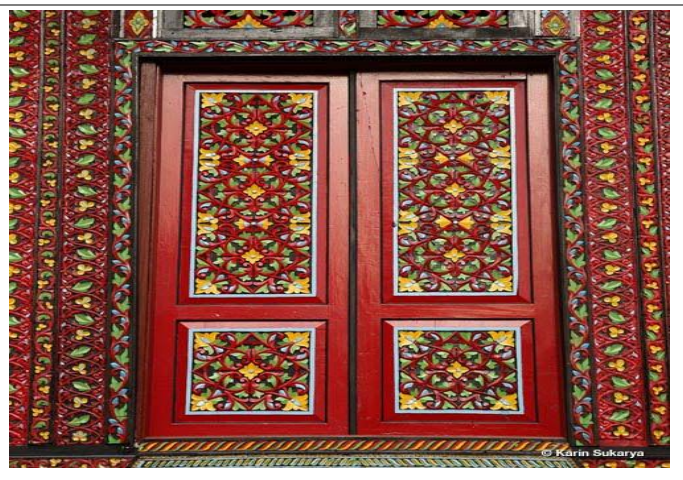




\section{3}

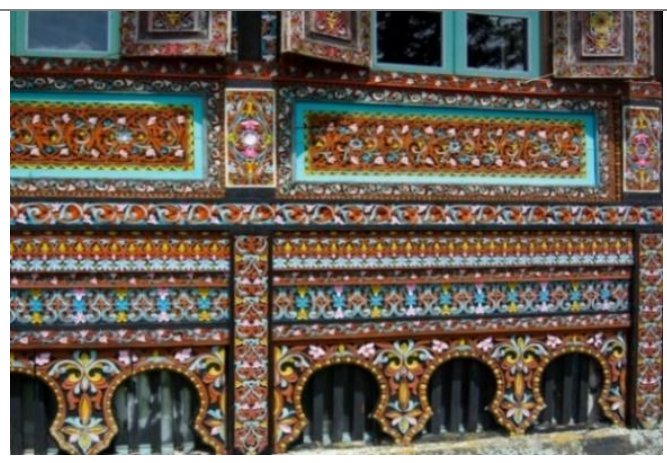

Pada dasarnya ukiran Rumah Gadang merupakan ragam hias pengisi bidang dalam bentuk garis melingkar atau persegi. Motif umumnya tumbuhan merambat, akar yang berdaun, berbunga dan berbuah. Pola akar biasanya berbentuk lingkaran, akar berjajaran, berhimpitan, berjalinan dan juga sambung menyambung. Cabang atau ranting akar berkeluk ke luar, ke dalam, ke atas dan ke bawah. Disamping motif akar, motif lain yang dijumpai adalah motif geometri bersegi tiga, empat dan genjang. Motif daun, bunga atau buah dapat juga diukir tersendiri atau secara berjajaran.

Fraktal adalah benda geometris yang kasar pada segala skala, dan terlihat dapat "dibagi-bagi" dengan cara yang radikal. Beberapa fraktal bisa dipecah menjadi beberapa bagian yang semuanya akan mirip dengan fraktal aslinya. Fraktal dikatakan memiliki detil yang tak hingga dan dapat memiliki struktur serupa pada tingkat perbesaran yang berbeda. Pada banyak kasus, sebuah fraktal bisa dihasilkan dengan cara mengulang suatu pola, biasanya dalam proses rekursif atau iteratif. Seperti pola yang ada pada ukiran rumah gadang Minangkabau yang terdapat pengulangan suatu pola.

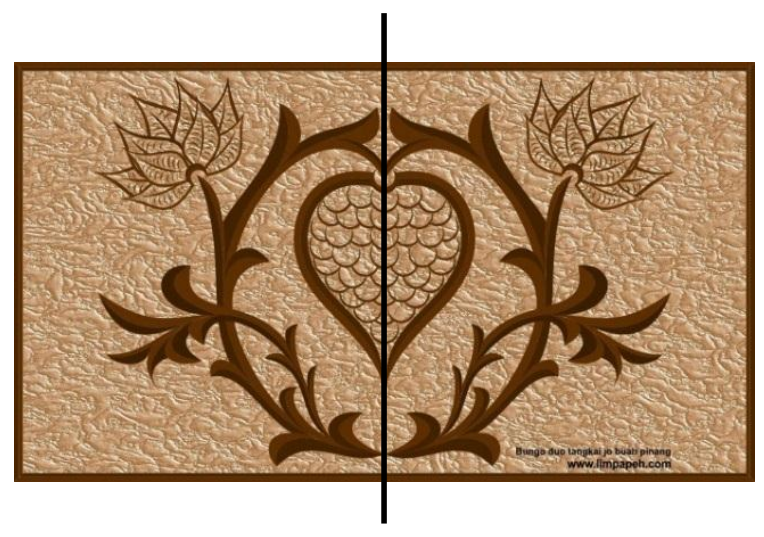

Gambar 9. Motif Ukiran Bungo Duo Tangkai jo Buah Pinang

Pembuatan motif ukiran Bungo Duo Tangkai jo Buah Pinang diawali dengan pola dasar lingkaran. Setelah itu, dilukis pola daun yang merambat dan bunga yang kembang. Dari pola tersebut terlihat adanya kesimetrisan antara pola kanan dan kiri (Gambar 9).

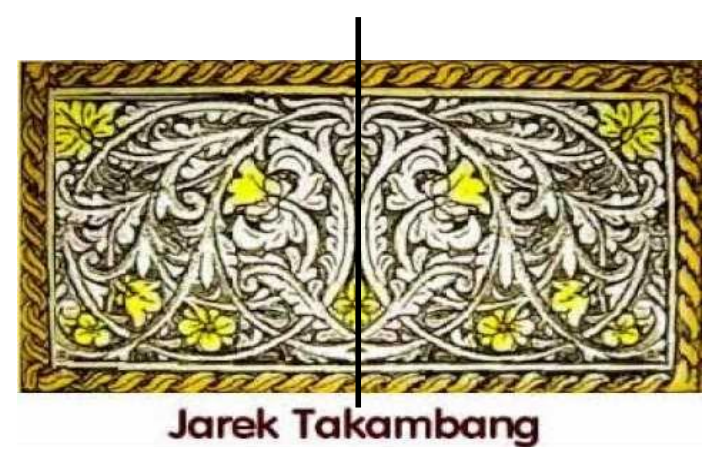

Gambar 1o. Motif ukiran Jarek Takambang

Gambar 10 memperlihatkan motif ukiran jarek takambang memiliki pola dasar lingkaran dari motif daun dan bunga yang melingkar berjalin dan sambung meyambung. Dari motif tersebut terlihat baha ada pengulagan pola yang menyebabkan terjadinya geometri fraktal. 


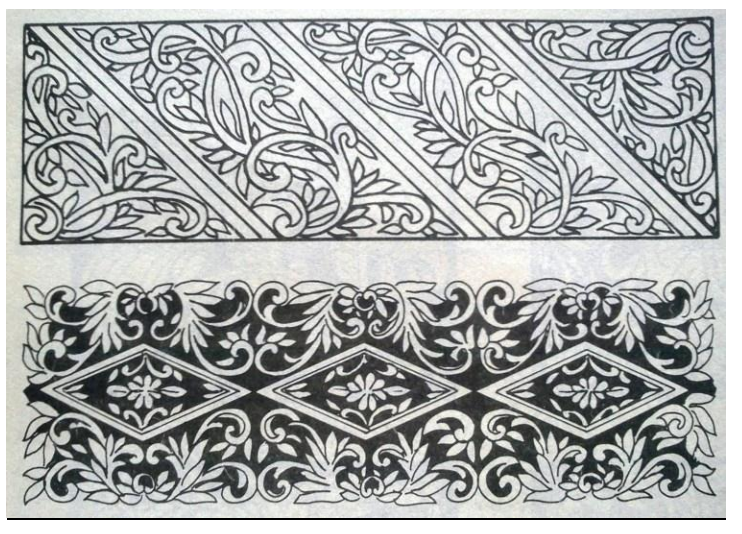

\section{Gambar 11. Motif Ukiran Lainnya}

Beberapa unsur matematika lain yang ada dalam pola ukiran ini antara lain megenai garis, antara lain: garis vertikal dan horizontal, garis sejajar, dan garis berpotongan. Selain itu, terdapat unsur simetris, bangun datar seperti: persegi, segitiga, jajargenjang, lingkaran, dan belah ketupat.

Keberadaan geometri fraktal menunjukkan bahwa matematika bukanlah subjek yang kering dan datar, tetapi merupakan suatu subjek yang indah dan dapat menghasilkan karya-karya yang memiliki citra seni dan nilai intelektual yang tinggi. Geometri ini menghasilkan keindahan yang sangat luar biasa. Warisan leluhur berupa seni ukir Minangkabau ini telah menunjukkan bahwa nenek moyang kita juga mengenal keindahan lewat geometri fraktal matematika. Hanya saja mungkin mereka belum menyadari bahwa hasil karyanya merupakan geometri fraktal.

\section{KESIMPULAN}

Berdasarkan hasil dan pembahasan yang telah dipaparkan sebelumnya, dapat disimpulkan bahwa hasil penelitian menunjukkan dalam aktivitas pembuatan rumah gadang minangkabau terdapat unsur dan konsep matematika yang digunakan.
Tanpa mempelajari teori tentang konsep matematika tersebut, masyarakat Minangkabau telah menerapkan konsep matematika dalam kehidupan sehari-hari menggunakan etnomatematika. Terbukti adanya bentuk etnomatematika masyarakat minangkabau yang tercermin melalui berbagai hasil aktivitas dan kegiatan matematika yang dimiliki dan berkembang di masyarakat minangkabau, meliputi: 1) aktivitas membuat rancangan pembangunan rumah gadang; dan 2) aktivitas membuat pola ukiran pada motif ukiran dinding rumah gadang. Hasil penelitian ini serupa dengan penelitian yang dilakukan Rachmawati (2012) menunjukkan bahwa tanpa mempelajari konsep matematika sebelumnya, masyarakat Sidoarjo telah menerapkan konsep-konsep tersebut dalam kehidupan sehari-harinya menggunakan etnomatematika. Terbukti adanya konsepkonsep matematika yang terkandung dalam bangunan candi dan prasasti, satuan lokal masyarakat Sidoarjo, bentuk geometri gerabah tradisional, motif kain batik dan bordir, serta permainan tradisional masyarakat Sidoarjo.

\section{REFERENSI}

Abdullah, M., Antariksa, \& Suryasari, N. (2015). Pola Ruang Dalam Bangunan Rumah Gadang Di Kawasan Alam Surambi Sungai Pagu - Sumatera Barat. Jurnal Mahasiswa Jurusan Arsitektur Universitas Brawijaya, o3(01).

Andika, R. P. (2014). Uraian Tentang Atap Dan Deskripsi Rumah-Rumah Adat Seluruh Indonesia. Retrieved from http://rakaraperz.blogspot.co.id/2014 /o8/Uraian-tentang-atap-dandeskripsi-rumah-rumah-adat-seluruhindonesia.html 
Arikunto, S. (2013). Prosedur Penelitian. Jakarta: Rineka Cipta.

D'Ambrosio, U. (1985). Ethnomathematics and its place in the history and pedagogy of mathematics. Retrieved from

http://www.math.utep.edu/Faculty/p mdelgado2/Math1319/History/DAmbr osio.pdf

Fajriyah, E. (2018). Peran Etnomatematika Terkait Konsep Matematika Dalam Mendukung Literasi. Jurnal Prisma 1, Prosiding Seminar Nasional Matematika, 1, 114-119.

Fauziah, \& Niniwati. (2017). EthnoMathematics Exploration On The Carvings Of Rumah Gadang In South Solok. Ijrdo-Journal Of Educational Research, o2(11), 134-148.

Fauziah, \& Yusfitri, R. Al. (2018). EthnoMathematics In Learning Mathematics On The Material of The Social Arithmetic In The Tradition Of Malamang In Nagari Ulakan Pariaman. American Journal of Engineering Research (Ajer), 7(10), 271-275.

Fitriza, R., Afriyani, D., Turmudi, \& Juandi, D. (2018). The Exploration Of EthnoMathematics Embedded On Traditional Architecture Of Rumah Gadang Minangkabau. 16o(Incomed 2017), 270-276.

Koetjaraningrat. (1985). Pengantar Ilmu Antropologi. Jakarta: Aksara Baru.

Pangestu, P., \& Santi, A. U. P. (2016). Pengaruh Pendidikan Matematika Realistik Terhadap Suasana Pembelajaran Yang Menyenangkan Pada Pelajaran Matematika Sekolah Dasar. Fibonacci: Jurnal Pendidkan Matematika Dan Matematika, 2(2), 58-71.

Puspadewi, K. R., \& Putra, I. G. N. N. (2014). Etnomatematika Di Balik Kerajinan Anyaman Bali. Jurnal Matematika,
4(2), 80-89.

Rachmawati, I. (2012). Eksplorasi Etnomatematika Masyarakat Sidoarjo. Mathedunesa, 1(1).

Ratna, N. K. (2005). Sastra Dan Cultural Studies: Representasi Fiksi Dan Fakta. Yogyakarta: Pustaka Pelajar.

Sroyer, A. M., Nainggolan, J., \& Hutabarat, I. M. (2018). Exploration Of Ethnomathematics Of House And Traditional Music Tools Biak-Papua Cultural. Formatif: Jurnal Ilmiah Pendidikan Mipa, 8(3), 175-184.

Wahyuni, A., Aji, A., Tias, W., \& Sani, B. (2013). Peran Etnomatematika Dalam Membangun Karakter Bangsa. Penguatan Peran Matematika Dan Pendidikan Matematika Untuk Indonesia Yang Lebih Baik, 113-118. Yogyakarta: Fmipa Uny.

Wahyuni, I. (2016). Eksplorasi Etnomatematika Masyarakat Pesisir Selatan Kecamatan Puger Kabupaten Jember. Fenomena, 15(2), 225-238. 